\title{
Comparison of the Experimental and predicting Data of Drying Characteristics of Cocoa Pod Using Cabinet Dryer at Different Temperature
}

\author{
Adeosun, Y.M*, Koyenikan, O.O, and Lasisi, M.O \\ Department of Agricultural and Bio-Environmental Engineering, The Federal Polytechnic, Ado-Ekiti, Nigeria \\ *Corresponding author
}

DOI: https://dx.doi.org/10.51584/IJRIAS.2021.6304

\begin{abstract}
Cocoa pod husks serve as potential sources of disease transmission in cocoa farms when it is not properly handled, Therefore, quick-drying is essential to prevent deterioration. This study evaluated the drying characteristics of cocoa pod husk as affected by drying at different temperatures $70^{\circ} \mathrm{C}, 80^{\circ} \mathrm{C}$ and $90^{\circ} \mathrm{C}$ and the effect of the drying system. This was achieved by developing a mathematical model in a cabinet dryer.The change in moisture content of the cocoa pod husk was monitored at regular intervals of $30 \mathrm{~min}$ until the moisture content of the sample became constant. The result shows that the drying rates were higher for the highest temperature $\left(90^{\circ} \mathrm{C}\right)$ used in this experiment and decreases with the decrease in dry air temperatures.The model was then validated with the data obtained from the cabinet dryer and there was no significant difference between the experimental drying rate and predicted values at $5 \%$ level significance. Midili kucuk $\left(0.989 \leq R^{2} \leq 0.998\right)$ and Hii et al $\left(0.983 \leq R^{2} \leq 0.996\right.$, ) models were selected as the best model for predicting the drying characteristics of cocoa pod.
\end{abstract}

Keywords:Experimental, Data, Modelling, Predicting, Cocoa pod, husks and Drying

\section{INTRODUCTION}

$\mathrm{T}$ he cocoa (Theobroma cacao) is the most prominent in the market among the 22 species of the Theobroma genusandis also claimed to be the only commercially cultivated (World Agriculture, 2011).Cocoa belongs to the Sterculiaceae family; is one of the most important tropical crops worldwide.In animal feeding trials, one of the agro byproducts that have optimum results is cocoa pod husk meal (Barnes et al., 1985). The cocoa pod husk is one of these byproducts which is about $75 \%$ weight of the whole fruit (Laconi, 2015 and Aregbgheore, 2002).Unfortunately, these cocoa pod husks are leftand discardedon the cocoa plantation transmitting diseases such as black pod rot, producing foul odors, polluting the environment, etc. (Forero-Nunez et al., 2015 and Mansur et al., 2014).Itis necessary removing the beans from the pods for chocolate producing which generates huge quantities of by-products (Vriesmann et al., 2011 and Sira, 2015). Presently, one of the major by-product causing environmental pollution problems in cocoa-producing areas of the world is cocoa pod husks. They serve as potential sources of disease transmission when used as mulch in cocoa farms. However, when properly processed to reduce the theobromine content and promote digestibility; in meal form, it can be used in livestock feed formulation as a valuable ingredient. Lopez et al., (1984) Reports have shown that each ton of dry cocoa (beans) represents ten (10) tonnes of cocoa pod husk. Drying is a method of food preservation in which food is dried (dehydrated or desiccated). Drying is said to be a mass transfer process consisting of the removal of water or another solvent by evaporation from a solid, semi-solid, or liquid. It is also the total removal or reduction of moisture content from agricultural produce to provide products that can be safely stored for a longer period (Alamu et al., 2010). It involves the removal of moisture from agricultural produce to provide a product that can be safely stored for a longer period. The most important aspect of drying technology is the mathematical modelling of the drying processes and the principle of modelling is based on having a set of mathematical equations that can adequately characterize the system. In particular, the solution of these equations must allow the prediction of the process parameters as a function of time at any point in the dryer, based only on the initial conditions (Gunhan et al., 2005). However, Kucuk et al., (2014) reported that the thickness of a thin layer can be increased provided there is an increase in the drying air velocity and also if the simultaneous heat and mass transfers of the material are in equilibrium with the thermodynamic state of the drying air. Erbay and Icer (2010) reported that the mechanisms of drying all kinds of foods include surface diffusion, liquid/vapor diffusion, and capillary action within the porous region of foods. However, it has been widely reported that the dominant mechanism of moisture removal from fruits and vegetables is diffusion (Akpinar 2006a; Doymaz 2007; Raquel 2007; Duc et al., 2011; Hashim et al., 2014). Further, the rate ofdiffusion depends on the moisture content and the nature of the material. Diffusion determines the drying rate, which can be expressed as the moisture content changes ( $g$ of water/g of solid).

However, during drying, the dominant mechanism can change due to a change in the physical structure of the drying solid after a long period (Jangam and Mujumdar 2010). Thus, determining the dominant mechanism can be very useful information in regards to modeling the drying process of fruits and vegetables, the initial drying period, the equilibrium air temperature (Turb) is usually greater than the temperature of 
the product (Carrin and Crapiste 2008). The objective is to allow design engineers to choose the most suitable operating conditions and then to size the drying equipment and drying chamber to meet the desired operating conditions (Hawlader et al., 1997).This research work will initiate the drying process of the cocoa pod to upgrade or improve the competence and competitiveness of cocoa production and generate strongerrecognition of the challenges in the planning of drying cocoa husk to the moisture standard to feed animals, so therefore quick drying is essential to prevent deterioration.

\section{EXPERIMENTAL PROCEDURE}

The fresh mature cocoa husks used for this experiment weresourced from a Farm located in Ijan village along Federal Polytechnic Road, Ado-Ekiti, Ekiti State. other materials used were a laboratory oven, kitchen knife, electronics weighing balance, VernierCalliper and weighing can.The research was conducted at the Department of Agricultural and Environmental Engineering and Food Science and Technology Laboratory of the Federal University of Technology, Akure, Ondo State. The Fresh cocoa husks approximately the dimension of these pod husks was $18 \mathrm{~cm}$ length and $7 \mathrm{~cm}$ width,were cleaned, sorted and cut into half with three replicates. each sample was dried in a cabinet dryer as shown in figure 1 , at temperatures 70,80 , and $90^{\circ} \mathrm{C}$. The change in moisture content of the cocoa pod was monitored at regular intervals of $30 \mathrm{~min}$ until the moisture content of the sample became constant, the thickness of each sample was taken using a verniercaliper. each sample was dried at temperatures 70,80 , and $90^{\circ} \mathrm{C}$., moisturecontent of the fresh cocoa pod was determined usingthe standard oven drying method at regular time intervals during the drying processes, samples were taken out of the oven for $24 \mathrm{~h}$ at $105^{\circ} \mathrm{C}$. The weighing was performed on a digital balance, and then moisture content (w.b.) was calculated using an equationand the tests were performed in triplicate

$$
M C=\frac{M_{w}-M_{d}}{M_{w}} X 100 M C=\frac{M_{w}-M_{d}}{M_{w}} X 100
$$

Where $\mathrm{MC}$ is the moisture content on a wet basis, $M_{w}$ is the weight of the wet sample and $M_{d}$ is the weight of a dried sample of cocoa pod husk. Moisture Ratio and Drying Rate The moisture ratio (MR) of samples was calculated using the equation

$$
M R=\frac{M_{t}-M_{e}}{M_{0}-M_{e}} \quad M R=\frac{M_{t}-M_{e}}{M_{0}-M_{e}}
$$

Where $\mathrm{Me}$ is the equilibrium moisture content of the sample ( $\mathrm{g}$ water/g dry solid). The value of $\mathrm{Me}$ is relatively small compared with Mt or M0, (Diamante and Munro, 1993). Therefore, Me was assumed to be zero in this study.

Five mathematical models commonly used in drying studies of other agricultural materials were used to evaluate the relationship betweenmoisture ratio and drying time (drying curve) of the cocoa pod (Table 2.1). The experimental datawere also fitted with other regression equations; two of them with a high degree of fitting are also reported in this study. The model constants were estimated using Minitab 17 software. According to the nonlinear modelling procedure, three parameters, coefficient of determination (R2), reduced chi-square $(\chi 2)$, and root mean square error (RMSE) were used to evaluate the fit of tested models to the experimental data (Meeso, et al., 2007; Sharma et al., 2005; Togrul, 2006; Wang et al., 2007). The model used for describing the drying characteristics of blueberries under IR radiation heating had the lowest X2 and RMSE values and the highest R2 value (Togrul, 2006). Statistical values were defined with equations

$$
\begin{aligned}
& R^{2}=1-\frac{\sum_{i}^{N}\left(M R_{\text {exp }, i}-M R_{\text {pre }, i}\right)^{2}}{\sum_{i}^{N}\left(\overline{M R_{\text {exp }}}-M R_{\text {pre }, i}\right)^{2}} \\
& X^{2}=\frac{\sum_{i}^{N}\left(M R_{\text {exp }, i}-M R_{\text {pre }, i}\right)^{2}}{N-n} \\
& R M S E=\sqrt{\frac{\sum_{i}^{N}\left(M R_{\text {exp }, i}-M R_{\text {pre }, i}\right)^{2}}{N}}
\end{aligned}
$$

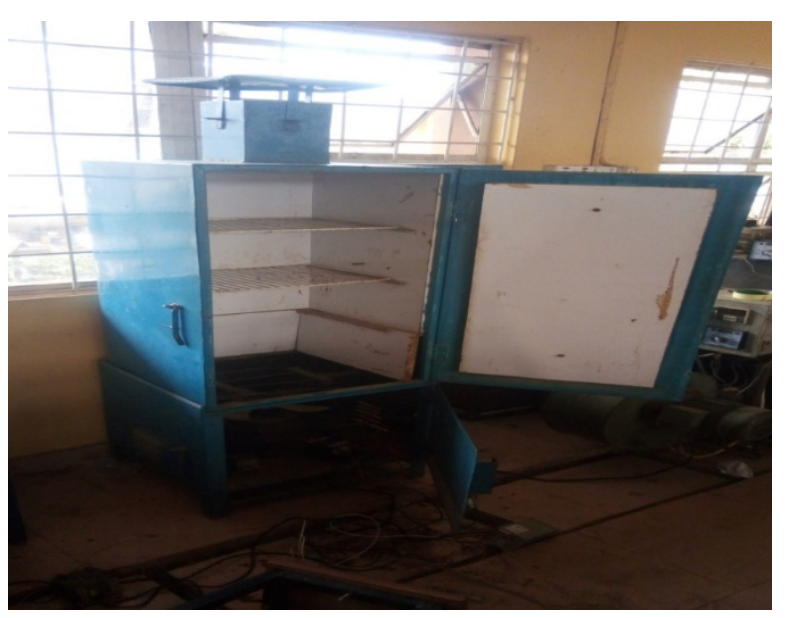

Plate 1: Electric Cabinet Dryer

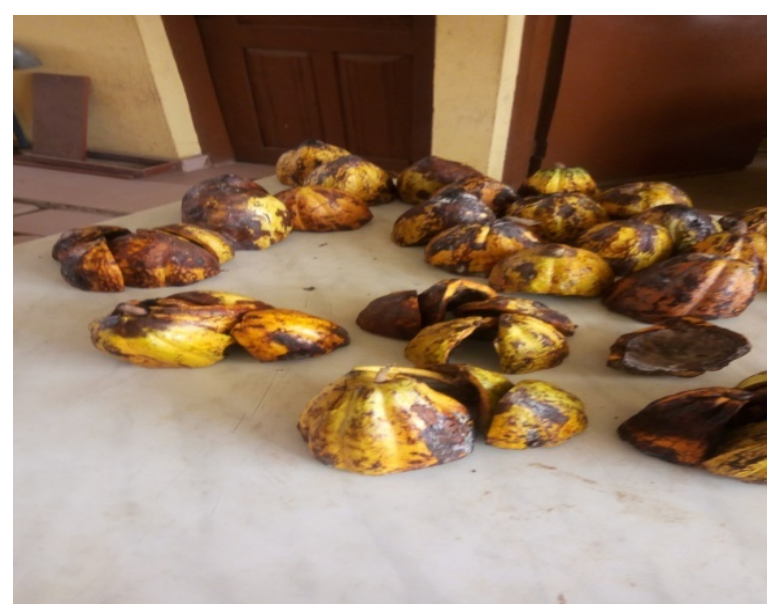

Plate 2: Fresh cocoa pod 


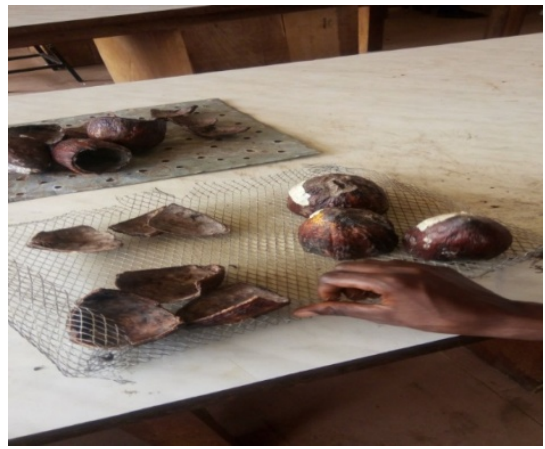

(a).

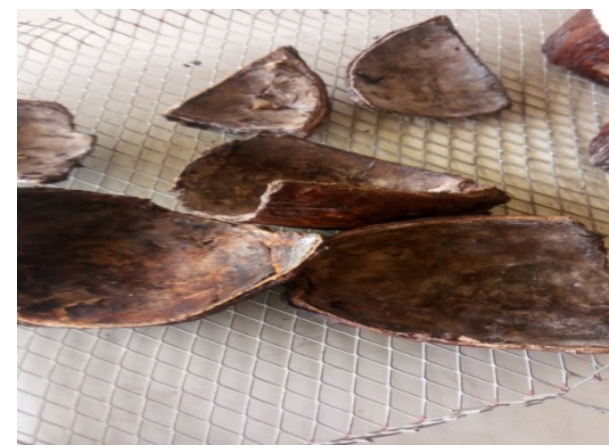

(b)

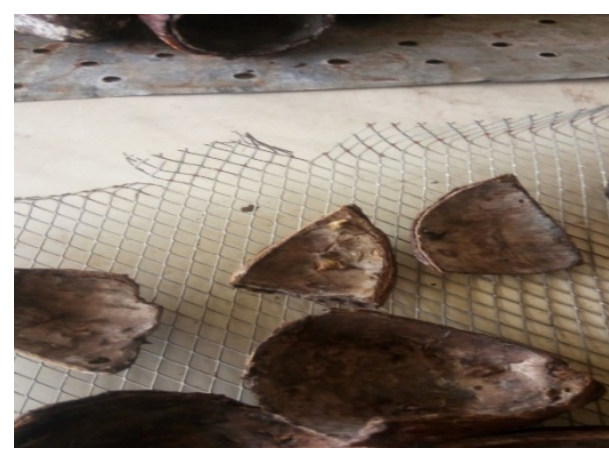

(c)

Plate 3: Electric cabinet drying of the cocoa pod at;(a, 90, b, 80 and c. $\left.70^{\circ} \mathrm{C}\right)$ Table 2.1Some thin layer drying models.

\begin{tabular}{|c|c|c|}
\hline Model Name & Model Equation & References \\
\hline Page & $M R=\exp \left(-k t^{n}\right)$ & Kaleemulla et al., (2006) \\
\hline Modified page & $\mathrm{MR}=\exp \left(-(\mathrm{kt})^{\mathrm{n}}\right)$ & $\begin{array}{c}\text { Goyal et al., (2007); } \\
\text { Ceylan et al. }(2007) \text {, Sogi } \\
\text { et al (2006); }\end{array}$ \\
\hline Logarithmic & $\mathrm{MR}=\mathrm{aexp}(-\mathrm{kt})+\mathrm{c}$ & $\begin{array}{l}\text { Babalis et al., (2006); } \\
\text { Celma et al.(2007); }\end{array}$ \\
\hline Wang and Singh & $\mathrm{MR}=1+\mathrm{at}+\mathrm{bt}^{2}$ & Wang and singh (1978) \\
\hline $\begin{array}{l}\text { ModifiedHenderson } \\
\text { and Pabis }\end{array}$ & $\begin{array}{c}\mathrm{MR}=\mathrm{a} \exp (-\mathrm{kt})+ \\
\operatorname{bexp}(-\mathrm{gt})+\operatorname{cexp}(- \\
\mathrm{bt})\end{array}$ & Karathanos (1999) \\
\hline Verma et al. & $\begin{array}{c}\mathrm{MR}=\mathrm{aexp}(-\mathrm{kt})+ \\
(1+\mathrm{a}) \exp (-\mathrm{gt})\end{array}$ & Doymaz, (2005); \\
\hline Midilli and Kucuk & $\begin{array}{c}\mathrm{MR}=\underset{\mathrm{bt})}{\operatorname{aexp}}\left(-\mathrm{kt}^{\mathrm{n}}+\right. \\
\end{array}$ & Midilli et al., (2002) \\
\hline
\end{tabular}

Where $\mathrm{MR}=$ moisture ratio (dimensionless); a, b, c, g, h, k, $\mathrm{k}_{1}, \mathrm{k}_{2}$ and $\mathrm{n}=$ drying constants; $\mathrm{t}=$ drying time $(\mathrm{h})$.

\section{RESULT AND DISCUSSION}

The statistical analyses undertaken on five thin layer mathematical models using cabinet dryer operated at drying air temperatures of 70,80 and $90{ }^{\circ} \mathrm{C}$ are given in Tables 3.1 to 3.3 respectively. The models were evaluated based on the coefficient of determination value $\left(\mathrm{R}^{2}\right)$, chi-square $\left(\chi^{2}\right)$ and root mean square error (RMSE) as reported by Ertekin and Yaldiz, (2004) and Gunhan et al., (2005). These curve fitting criteria for the three models were also shown in Table 1 to 3. For cabinet drying temperature of $90{ }^{\circ} \mathrm{C}$, the Midili kucuk model was the best descriptive model that accurately describes the drying behavior of the pod cocoa husk selected for study shown in Table 3.3 Generally, coefficient of determination value $\left(\mathrm{R}^{2}\right)$, chi-square $\left(\chi^{2}\right)$ and root mean square (RMSE) values varied between $0.865-0.998,0.000-0.017$, respectively. Also, from Table 3.3 it was noted that the $\mathrm{R}^{2}$, RMSE and $\chi^{2}$ for the best mathematical model (Midili Kucuk model) range from $0.989-0.998,0.015-0.044$, and $0.000-$ 0.002 . For, cabinet temperature 70 to $80^{\circ} \mathrm{C}$, the Hii et al. model was the best model that accurately describes the drying behavior of the cocoa husk selected in this study as shown in Tables 3.1 and 3.2 respectively. From Table 3.1, it was observed that the $\mathrm{R}^{2}$, RMSE and $\chi^{2}$ for the best mathematical model (Hii et al. model) range from 0.983 - 0.996, 0.0190.0711 , and $0.000-0.004$. Hence, the Midili kucuk and Hii et al. models gave better predictions than other models and satisfactorily described drying characteristics of cocoa pod husk at forced convection mode in a cabinet dryer.

Table 3.1: Model constant and goodness of fit parameter for cabinet drying $\left(70{ }^{\circ} \mathrm{C}\right)$

\begin{tabular}{|c|c|c|c|c|c|}
\hline Model & Model constant & $\mathrm{R}^{2}$ & $\begin{array}{c}\text { RMS } \\
\text { E }\end{array}$ & SEE & $\chi^{2}$ \\
\hline Page & $\begin{array}{c}\mathrm{k}=0.0235, \mathrm{n}= \\
1.7742\end{array}$ & $\begin{array}{c}0.966 \\
7 \\
\end{array}$ & $\begin{array}{c}0.064 \\
2 \\
\end{array}$ & $\begin{array}{c}0.066 \\
1 \\
\end{array}$ & $\begin{array}{c}0.003 \\
3 \\
\end{array}$ \\
\hline Logarithmic & $\begin{array}{c}\mathrm{k}=0.1208, \mathrm{a}= \\
1.2302, \mathrm{c}=- \\
0.0816\end{array}$ & $\begin{array}{c}0.943 \\
0\end{array}$ & $\begin{array}{c}0.076 \\
8\end{array}$ & $\begin{array}{c}0.080 \\
2\end{array}$ & $\begin{array}{c}0.010 \\
2\end{array}$ \\
\hline Midili kucuk & $\begin{array}{c}\mathrm{k}=0.0032, \mathrm{~b}= \\
0.0102, \mathrm{a}= \\
0.9379, \mathrm{n}= \\
2.9265\end{array}$ & $\begin{array}{c}0.993 \\
0\end{array}$ & $\begin{array}{c}0.027 \\
2\end{array}$ & $\begin{array}{c}0.028 \\
8\end{array}$ & $\begin{array}{c}0.008 \\
6\end{array}$ \\
\hline Hii et al. & $\begin{array}{c}\mathrm{k}=0.0055, \mathrm{~g}=- \\
0.0001, \mathrm{a}= \\
0.8377, \mathrm{c}= \\
0.1343, \mathrm{n}= \\
2.6995\end{array}$ & $\begin{array}{c}0.996 \\
3\end{array}$ & $\begin{array}{c}0.019 \\
7\end{array}$ & $\begin{array}{c}0.021 \\
2\end{array}$ & $\begin{array}{c}0.001 \\
0\end{array}$ \\
\hline Modified Page I & $\begin{array}{c}\mathrm{k}=1.041, \mathrm{a}= \\
0.0436, \mathrm{n}= \\
1.4974, \mathrm{~L}= \\
0.9899\end{array}$ & $\begin{array}{c}0.966 \\
5\end{array}$ & $\begin{array}{c}0.060 \\
8\end{array}$ & $\begin{array}{c}0.064 \\
5\end{array}$ & $\begin{array}{c}0.007 \\
1\end{array}$ \\
\hline
\end{tabular}

Table 3.2: Model constant and goodness of fit parameter for cabinet drying $\left(80{ }^{\circ} \mathrm{C}\right)$

\begin{tabular}{|c|c|c|c|c|c|}
\hline Model & Model constant & $\mathrm{R}^{2}$ & RMSE & SEE & $\chi^{2}$ \\
\hline Page & $\mathrm{k}=0.0027, \mathrm{n}=2.9681$ & 0.9924 & 0.0807 & 0.0823 & 0.0027 \\
\hline Logarithmic & $\begin{array}{c}\mathrm{k}=0.122, \mathrm{a}=1.1775, \\
\mathrm{c}=-0.0598\end{array}$ & 0.9321 & 0.0835 & 0.0861 & 0.0222 \\
\hline $\begin{array}{c}\mathrm{k}=0.0008, \mathrm{~b}= \\
\text { kucuk }\end{array}$ & $\begin{array}{c}0.0043, \mathrm{a}=0.9211, \mathrm{n} \\
=3.5888\end{array}$ & 0.9891 & 0.0405 & 0.0422 & 0.0071 \\
\hline
\end{tabular}




\begin{tabular}{|c|c|c|c|c|c|}
\hline Hii et al. & $\begin{array}{c}\mathrm{k}=0.0077, \mathrm{~g}= \\
0.0066, \mathrm{a}=0.9876, \mathrm{c}= \\
-0.028, \mathrm{n}=2.378\end{array}$ & 0.9831 & 0.0711 & 0.0750 & 0.0039 \\
\hline $\begin{array}{c}\text { Modified } \\
\text { Page I }\end{array}$ & $\begin{array}{c}\mathrm{k}=1.0375, \mathrm{a}= \\
0.0467, \mathrm{n}=1.572, \mathrm{~L}= \\
1.0757\end{array}$ & 0.9701 & 0.0656 & 0.0684 & 0.0075 \\
\hline
\end{tabular}

Table 3.3: Model constant and goodness of fit parameter for cabinet drying $\left(90{ }^{\circ} \mathrm{C}\right)$

\begin{tabular}{|c|c|c|c|c|c|}
\hline Model & Model constant & $\mathrm{R}^{2}$ & $\mathrm{RMSE}$ & $\mathrm{SEE}$ & $\chi^{2}$ \\
\hline Page & $\mathrm{k}=0.0281, \mathrm{n}=1.854$ & 0.9849 & 0.0403 & 0.0420 & 0.0040 \\
\hline Logarithmic & $\begin{array}{c}\mathrm{k}=0.0661, \mathrm{a}= \\
1.9266, \mathrm{c}=-0.8286\end{array}$ & 0.9595 & 0.0649 & 0.0692 & 0.0117 \\
\hline $\begin{array}{c}\mathrm{k}=0.0082, \mathrm{~b}= \\
\text { Midili } \\
\text { kucuk }\end{array}$ & $\begin{array}{c}0.0121, \mathrm{a}=0.9478, \mathrm{n} \\
=2.6504\end{array}$ & 0.9940 & 0.0250 & 0.0273 & 0.0108 \\
\hline Hii et al. & $\begin{array}{c}\mathrm{k}=0.0104, \mathrm{~g}= \\
0.0001, \mathrm{a}=0.8338, \mathrm{c} \\
=0.1377, \mathrm{n}=2.5629\end{array}$ & 0.9946 & 0.0236 & 0.0264 & 0.0057 \\
\hline $\begin{array}{c}\text { Modified } \\
\text { Page I }\end{array}$ & $\begin{array}{c}\mathrm{k}=1.0031, \mathrm{a}=0.058, \\
\mathrm{n}=1.8437, \mathrm{~L}= \\
1.4622\end{array}$ & 0.9849 & 0.0403 & 0.0440 & 0.0120 \\
\hline
\end{tabular}

The validation of the best model was analyzed by determination of the degree of linearity between the experimental data and the data gotten from the best thin layer mathematical model. The validation plot shows a very high degree of linearity between the predicted and the observed data and therefore it can be used to effectively and efficiently predict the drying behavior of cocoa pod husk with the degree of accuracy of about $99.42,99.00$, and $99.54 \%$ for 70,80 and $90{ }^{\circ} \mathrm{C}$ in the cabinet dryer. However, the graphical representation of the predicted data against the observed data is shown in Figures 1, 2, and 3 for cabinet drying.

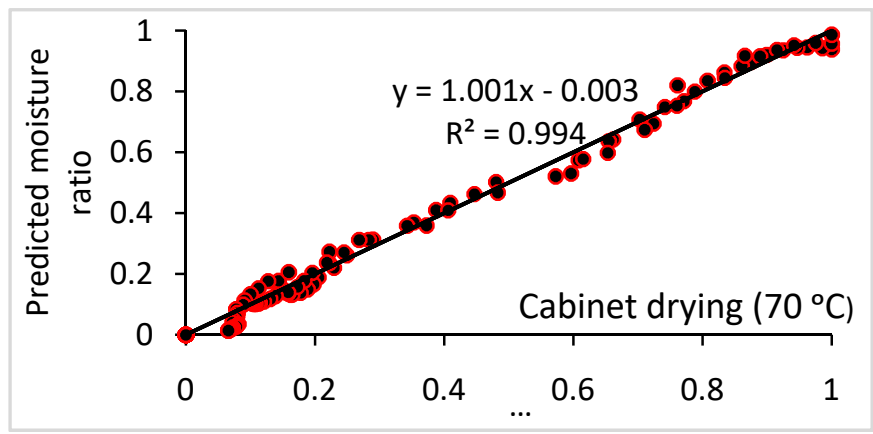

(a).

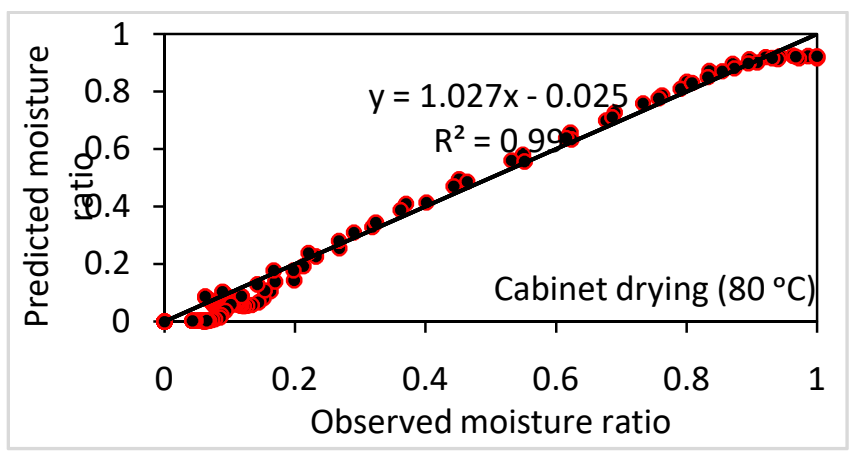

(b).

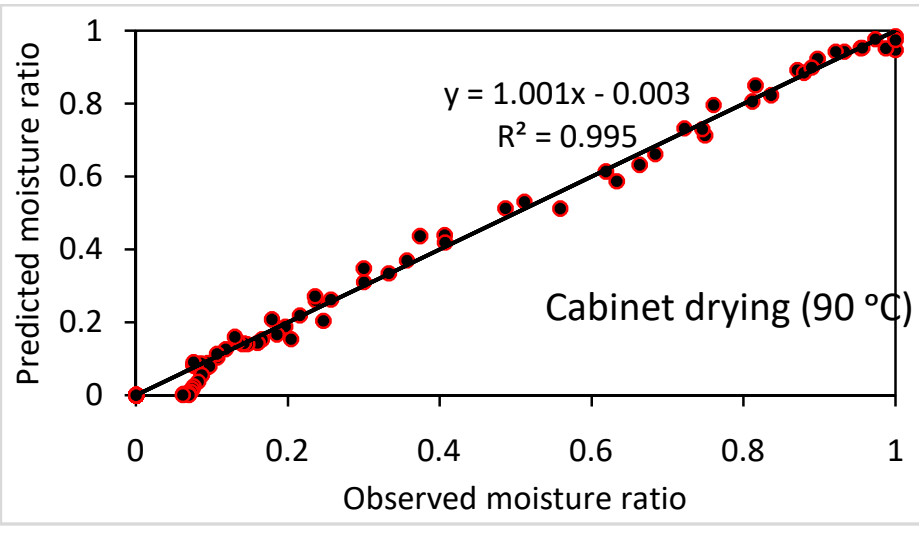

(c)

Comparison of the experimental and the predicted data for cabinet drying at a different temperature a, $70^{\circ} \mathrm{C} ; \mathrm{b}, 80^{\circ} \mathrm{C}$; and $\mathrm{c}, 90^{\circ} \mathrm{C}$

\section{CONCLUSION AND RECOMMENDATION}

\section{Conclusion}

i. The Midili kucuk $\left(0.989 \leq \mathrm{R}^{2} \leq 0.998,0.015 \leq\right.$ RMSE $\leq 0.044$, and $\left.0.000 \leq \chi^{2} \leq 0.002\right)$ and Hii et al model $\left(0.983 \leq \mathrm{R}^{2} \leq 0.996,0.019 \leq \mathrm{RMSE} \leq 0.0711\right.$, and $\left.0.000 \leq \chi^{2} \leq 0.004\right)$ models were adjudged the best model for predicting the drying characteristics of cocoa pod compared to other thin layer drying models.

ii. The cabinet drying was found to be more effective for moisture removal compared to other drying methods.

iii. The drying rates were observed to be higher for the highest temperature $\left(90^{\circ} \mathrm{C}\right)$ used in this study and decrease with the decrease in dry air temperatures.

iv. The moisture content and moisture ratio of cocoa pod husk decreased exponentially with drying time at all air temperatures and an increase in the drying air temperature resulted in a decrease in the amount of moisture removed from the cocoa pod husk

\section{Recommendations}

The following recommendations were made based on the scope, finding, and limitation of study of drying kinetics of different pod sizes of cocoa pod under cabinet dryer operated at drying air temperature of 70,80 and $90{ }^{\circ} \mathrm{C}$.;

i. The pod husk should be reduced to the minimum possible size to increase the rate of drying and ensure effective drying

ii. Drying of cocoa pod husk at $70{ }^{\circ} \mathrm{C}$ temperatures in the cabinet dryer could be used to increase the drying rate and conserve drying energy.

iii. The best calibrated mathematical model (Midili kucuk and Hii et al model) can be used for effective prediction of the drying characteristics of cocoa pod husk. 


\section{REFERENCES}

[1] Vriesmann, L.C.; Amboni, R.D.d.M.C. and de-Oliveira, C. L., (2011). Cacao pod husks (Theobromacacao L.): composition and hot-water-soluble pectins, Indian Crop Production. 34, 11731181.

[2] Barnes, A.R.; Amega, W.K.; Manu, M. and Rhule, T. (1985). Utilization of cocoa husk meal by growing-finishing pigs. Proceedings of 9th International Cocoa Research Conference, Lome, Togo, pp:449-454.

[3] Agyente-Badu, K. and Oddoye E.O.K. (2005). Uses of cocoa byproducts. Proceedings of 24th Biennial Conference of Ghana Science Association, University of Ghana, Legon, pp: 115-127.

[4] Laconi, E.B. and Jayanegara, A. (2015). Improving the nutritional quality of cocoa pod (Theobroma cacao) through chemical and biological treatments for ruminant feeding: in vitro and in vivo evaluation. Asian Australasian Journal of Animal Science, 28 (3), 343-350.

[5] Aregheore, E. (2002). Chemical evaluation and digestibility of cocoa (Theobroma cacao) byproducts fed to goats, Tropical Animal Health Production. 34, 339-348.

[6] Forero-Nuñez, C.; Jochum, J. and Sierra F. (2015). Effect of particle size and addition of cocoa pod husk on the properties of sawdust and coal pellets, Ing. Invest. 35, 17-23.

[7] Sira E. P. (2015). Chocolate: Cocoa Byproducts Technology, Rheology, Styling, and Nutrition, Nova Science Publishers Inc., London, 2015.

[8] Mansur, D.; Tago, T.; Masuda, T. and Abimanyu, H. (2014). Conversion of cacao pod husks by pyrolysis and catalytic reaction to produce useful chemicals, Biomass Bioenergy. 66, 275-285.

[9] Oddoye, E.O.; Agyente-Badu, C.K. and Gyedu-Akoto, E. (2013) Cocoa and Its By-Products: identification and utilization. In: Watson R., Preedy V., Zibadi S. (Eds.) Chocolate in Health and Nutrition. Nutrition and Health, 7, 23-38. New York, Springer.

[10] Lopez, A. S.; Ferrrira, H.I.S.; Limosas, C.A. and Romeu, A.P. (1984). Present status of cocoa by-products utilization in Brazil. Reserve Theobroma, 14(4): 271-291.

[11] Alamu, O.J; Nwaokocha, C.N and Adunola, O. (2010). Design and construction of a domestic passive solar food dryer, Leonardo Journal of Sciences, 71-82.

[12] Hawlader, M N A, Chou S K and Chua K J (1997).Development of design charts for tunnel dryers.International Journal of Energy Research 21(11):1023-1037

[13] Gunhan, T., Demir, V., Hancioglu, E., Hepbasli, A. (2005). Mathematical modelling ofdrying of bay leaves. Energy Convers. Manage. 46, 1667-1679

[14] Kucuk, H.; Midilli, A.; Kilic, A. and Dincer, I. (2014). A review on thin-layer drying-curve equations. Drying Technology 32(7):757-73

[15] Erbay, Z. and Icier, F. (2010). A review of thin-layer drying of foods: theory, modelling, and experimental results. Crit Reserve Food Science Nutrient 50(5):441-64

[16] Akpinar, E. K., (2006a). Determination of suitable thin-layer drying curve model for some vegetables and fruits. Journal Food Engineering 73:75-84.

[17] Doymaz, I. (2007). The kinetics of forced convective air-drying of pumpkin slices. Journal Food Engineering 79:243-8

[18] Raquel, P. F.; Susana, P. and Maria, J. B. (2011). Study of the convective drying of pumpkin (Cucurbitamaxima). Food Bioproduct Process 89:422-8

[19] Duc, L. A.; Woong, H. J. and Hyuk, K. D. (2011). Thin-layer drying characteristics of rapeseed. Journal Stored Products Resources 47:32-8.

[20] Hashim, N.; Onwude, D. and Rahaman, E. (2014). A preliminary study: the kinetic model of drying process of pumpkins (Cucurbita moschata) in a convective hot air dryer. Agriculture Science Procedia 2(2):345-52.

[21] Jangam, S. V. and Mujumdar, A. S. (2010). Basic concepts and definition. In: Jangam SV, Law CL, Janisiewicz, W. J., Conway W. S. and Leverentz. B. (1999). Biological control of postharvest decays of apple can prevent the growth of Escherichia coli O157:H7 in apple wounds.Journal of Food Protection. 62:13721375.

[22] Carrin, M. E. and Crapiste, G. H., (2008). Convective drying of foods. In: Ratti C, editor. Advances in food dehydration. Boca Raton, FL: CRC Press. 123-152.

[23] Kaleemullah, S. and Kailappan, R. (2006). Modelling of thin-layer drying kinetics of red chilies. Journal of Food Engineering, 76 (4): 531-537

[24] Goyal, R. K.; kingsley, A. R. P.; Manikantan, M. R. and Ilyas, S. M. (2007). Mathematical modelling of thin-layer drying kinetics of plum in a tunnel dryer. Journal of Food Engineering, 79: 176-180

[25] Celma, A. R.; Rojas, S.; Lopez, F.; Montero, I., and Miranda, T. (2007). Thin-layer drying behaviour of sludge of olive oil extraction. Journal of Food Engineering, 80: 1261-1271

[26] Sogi, D. S., Shivahare, U.S., Garg, S.K and Bawa, S.A. (2003). Water sorption isotherms and drying characteristics of tomato seeds. Biosystems Engineering, 84(3): 297-301.

[27] Babalis, S. J.; Papanicolaou, E.; Kyriakis, N., and Belessiotis, V.G. (2006). Evaluation of thin-layer drying models for describing drying kinetics of figs (Ficus carica). Journal of Food Engineering, 75(2): 205-214

[28] Celma, A. R., Rojas, S. and Lopez-Rodriguez, F.(2007). Mathematical modeling of thin-layer infrared drying of wet olive husk. Chemical Engineering and Processing 47: 1810-1818

[29] Wang, C.Y. and Singh, R.P. (1978). A single layer drying equation for rough rice. American society Agricultural engineering, paper No. 78-3001, St. Joseph, MI, USA.

[30] Karathanos, V. T. (1999). Determination of water content of dried fruits by drying kinetics. Journal of Food Engineering 39:337-344

[31] Midilli, A.; Kucuk, H. and Yapar, Z (2002). A Hii et al. model for single-layer drying. Drying Technology, 20(7): 1503-1513

[32] Kar, A., and Gupta, D. K. (2003). Air drying of osmosis button mushrooms. Journal of Food Science and Technology, 40(1), 2327

[33] Erteken, C. and Yaldiz, O. (2004). Drying of eggplant and selection of a suitable thin layer drying model. Journal of Food Engineering. 63:349-359.

[34] Gunhan, T., Demir, V., Hancioglu, E., Hepbasli, A. (2005). Mathematical modelling ofdrying of bay leaves. Energy Convers. Manage. 46, 1667-1679 